\title{
CDK2 Gene
}

National Cancer Institute

\section{Source}

National Cancer Institute. CDK2 Gene. NCI Thesaurus. Code C24284.

This gene is involved in G2/M cell cycle regulation. 